\title{
Inclusion of Global Citizenship Education and Sustainable Development in Pre-Service Curriculum: A Perspective Study
}

\author{
Nasreen Bano ${ }^{1}$, Khushbakht Hina ${ }^{2}$
}

\begin{abstract}
Education Agenda 2030 emphasizes the role of Sustainable Development Goal 4 which focuses on excellence in education and its prominence for the attainment of sixteen other sustainable development goals. For this purpose a study was carried out to investigate the opinions of Educationists/Curriculum developers for inclusion of themes of Global Citizenship Education (GCED) and Education for Sustainable Development (ESD) in Pre-Service Teacher Education Curriculum (Elementary) level in Pakistan. There are six broad themes of GCED and ESD: Human Rights, Education for sustainable Development, Peace, Gender Equality, Health Education and Global Citizenship. It was a descriptive study. On the predetermined themes suggested by UNESCO, a survey questionnaire was developed having both open and close-ended questions. There were 70 participants in the study who were M.Phil to Post Doctorate and had professional experience of $10-35$ years. Data for close-ended questionnaire were analyzed through SPSS 21 and the qualitative part used descriptive explanation with verbatim quotes and word clouds using NVIVO 10. The results showed that participants strongly favored inclusion of these themes in curriculum and believed these to be cross cutting themes. It was recommended that these may either be integrated into already existing subjects of B.Ed. or may be taught as separate subjects.
\end{abstract}

Keywords: Pre-Service Curriculum, Target 4.7, Global Citizenship Education, Education for Sustainable Development

\section{Introduction}

Education is very important in this co-dependent world and the advancement of any country or individual depends upon the quality of education. UNESCO's role is commendable in bringing countries together, to cater both present and future needs in attaining progress, eminence, and relevance in education (UNESCO, 2014). Besides this, the main concern of the world now is to eradicate poverty in all its forms from society and establish peace. For this

\footnotetext{
${ }^{1}$ Ph.D Scholar, National University of Modern Languages, Islamabad

Email: manonasreen11@gmail.com

${ }^{2}$ Assistant Professor, National University of Modern Languages, Islamabad Email: kbhina@numl.edu.pk
} 
purpose, distinguished personalities of the world agreed to work on the future global agenda. Hence, Sustainable Development Goals were framed in 2015. Goal 4 was dedicated to Education. It had seven targets and three operation processes (Tang, 2015). A global commitment was made to provide superior educational opportunities to every member of the society without making discrimination of any form. The need was also felt to educate people not only in the formal set up but to continue their learning both in and outside the schools and all over their life span. Besides this, it was committed to provide them a safe physical and psychological environment (Desa, 2016).

Learning wherever carried out must be applicative, effective, and as per the needs of the changing times (UNESCO 2016b). In Pakistan, educational system must focus on making the youth productive so that they do not fall prey to extremism, regionalism and fanaticism. Besides this, strong Islamic and ethical values may be developed, for making them devoted and loyal citizens (Aamer, 2009). Generally it is witnessed that countries with highly skilled workforce develop economically and are aware of their own rights as well as the rights of others and pave way to prosperous societies (Osman, Ladhani, Findlater \& McKay, 2017).

It is expected from the future learners to attain knowledge, skills and competencies which enable them to prudently utilize the available natural resources as well as save them for the coming generations to have uninterrupted supply. For this it requires collaborative efforts of public and private institutions and partnerships among all nations of the world (Rieckmann, 2017).

\subsection{Statement of the Problem}

Global Education Monitoring Report (UNESCO, 2016b, p. 289) asks the member states of the United Nations to investigate and monitor the topics of SDG Target 4.7 related to GCED and ESD in the syllabi, texts, instructor education packages, and the students' analysis/assessments. As the SDGs, were also signed by Pakistan, the investigators tried to find out the opinions of experts in the field of curriculum and education to see how far they agree to the inclusion of themes of Target 4.7 in Pre-Service B.Ed. Honors (Elementary) curriculum and how effective they find this for the Pre-Service teachers in the attainment of Education Agenda 2030.

\subsection{Significance of the Study}

This study will be highly significant to the policy makers for making amendments in the policies as per expert opinions, for the inclusion of global citizenship education and education for sustainable development so that they can take policy decisions for its implementation in the, curricular documents, teacher educational institutions, and schools. It can be beneficial for the teacher 
educators, student teachers and learners so that they develop the knowledge, competencies, skills and values in adopting sustainable life styles. The study can be useful for the global monitoring report to know the views of educationists in Pakistan regarding the inclusion of GCED and ESD in the teacher education curriculum.

\subsection{Objectives of the Study}

The objectives of the study are:

1. To inquire the extent to which Educational Experts/Curriculum developers agree for the inclusion of GCED and ESD themes in the Pre-Service Teacher Education Curriculum

2. To explore the educational expert opinions about how Global Citizenship Education and Education for Sustainable Development benefit the prospective teachers in attaining Education Agenda 2030.

\section{$1.4 \quad$ Research Questions}

1. To what extent the Educational Experts/Curriculum Developers agree for the inclusion of the themes of GCED and ESD in the B.Ed. (Honors) Elementary Curriculum?

2. As per Educational Experts/Curriculum Developers, how can the inclusion of GCED and ESD themes in the Pre-Service Teacher Education Curriculum help the Prospective Teachers in the attainment of SDG Education Agenda 2030 ?

\section{Literature Review}

The Agenda for Education 2030 was the determination of large number of people of this globe. Members of the United Nations realized that poverty could be removed only with 'Quality Education' (Desa, 2016).

Sustainable Development Goal (SDG) 4 states:

Ensure inclusive and equitable quality education and promote life-long learning opportunities for all (UNESCO, 2016a p. 7).

Education is the process of acquiring knowledge, skills, and behaviors. The curriculum is the heart of learning which brings positive change in behaviors. (Lewin, 2016). It was witnessed that traditionally designed curricula, mentioned citizenship education by emphasizing more on the attainment of content knowledge (Cox, 2017). Curriculum of B.Ed. (Honors) Elementary was designed to make the prospective teachers competent in their fields as the doctors, engineers, lawyers or other graduates who pursue four years of bachelor education (HEC, 2012). It is developed keeping the ideological basis of the country, its philosophy, the culture, and its vision in mind (Haider, 2016). Still our curriculum put very little focus on tolerance, social justice, democracy, regional and social culture (Chishti, Tahirkheli, Raja \& Khan, 2011). 
The pedagogies used for GCED are learner centered, peer learning, use of ICT, more democratic learning with open debates and whole school approach (IBE- UNESCO, 2016). Similarly, the pedagogies used according to B.Ed. (Honors) Elementary curriculum in Pakistan are peer learning, making debates, giving presentations, using discussion, working in groups, role playing and learning through enquiry. Courses on teacher leadership however are missing, and the curriculum mostly focused on educational management and functions (Rizvi, 2015).

Progress of any country cannot be made without education and Pakistan is confronted with several social, political and economic problems. Lack of peace and political stability is also making Pakistan economically weak (Ahmad, 2014). Amin, Jumani and Malik (2020) proclaim that 'peace' is unavoidable for society as it cultivates consideration and kindness for others, in the learners. Teachers can play an important role in educating for peace as they feel responsible for developing peaceful learners who could be just and fair to others.

According to Human Rights Declaration 1948, all people are free and have the right to live a respectable and dignified life, free from all sort of violence, abuse, and bullying. (Osman, Ladhani \& Findiater, 2015). Importance of Human Rights Education is stressed in the curricula and policies of Pakistani documents but very little of teaching on Human Rights is witnessed in the class rooms (Pirzado, 2019). Similarly we see very dismal status of women in Pakistan. The working women are more burdened as compared to men (Iqbal, Afzal \& Inayat, 2012). Therefore, the human rights, the status of women, the extremism in Pakistan and the poor education scenario prompts Pakistan for inclusion of the themes of GCED and ESD. Education for Sustainable Development (ESD) was considered as the umbrella term for sustainability till 2012, now GCED and ESD are collectively merged in Target 4.7 of the SDGs (UNESCO, 2013).

To investigate if the ESD themes includes in the key educational documents Kalsoom et.al studied, National Professional standards for teachers, Accreditation for teachers of Pre-service and B.Ed. elementary curriculum. Their results were very surprising and they found that the curriculum of B.Ed. had only $5 \%$ of sustainability included in it. They expressed their concern for non-inclusion of sustainability in all three documents of teacher preparation program (Kalsoom, Qureshi \& Khanum, 2019 p 20-33).

Another study carried out to find the integration of Education for Sustainable Development in the curriculum of B.Ed. (Honors) Elementary, having three significant constituents of society and culture, environment and economy found that the environmental component was missing in up to $93 \%$ in 
the teacher education program, similarly the economic component which included poverty, preserving natural resources, illiteracy etc. was missing by $96 \%$, the social and cultural component which included tolerance, peace, harmony, preservation of cultural heritage, international understanding and citizens' rights were not aligned by $90 \%$. But the NCRC members highly favored the integration of these components and recommended the revision of curriculum of B.Ed. 2012 (Durrani, Malik, \& Jumani, 2019 p 75-81). Curricula with very strong national values and attitudes may be designed and efforts need to be made for its connection with the world and the role of Pakistani citizens in this inter-linked world must be defined. Until this connection is established the citizens of any country would prioritize the goals of their nation before the global goals. Clear understanding of national citizenship is required to understand the global citizenship and learners in Pakistan may be given more opportunities to interact with their global peers and must be taught about the inter-connectedness and the interdependency of the nations with other nations (Pasha, 2015).

\section{Research Methodology}

\subsection{Research Design}

The study is exploratory and descriptive in nature. Survey questionnaire was used to collect the data. It has both closed and open-ended questions. The quantitative part used the descriptive statistical measure of numbers and percentages along with graphs while the qualitative part used the descriptive explanation with verbatim quotes and word clouds using NVIVO 10. Both of these methods allow providing different ways to answer different questions (Cohen, Manion, Morrison, 2013).

\subsection{Population}

The population of the study was all curriculum developers at Secondary, Elementary and ADE levels. The list was taken from HEC. The Reviewers of the National Curriculum Review Committee (NCRC) were about 29 members and 81 subject experts were those who were involved in developing different course guides/ teaching-learning and resource material of B.Ed., Elementary under the supervision of NCRC members.

\subsection{Sample and Sampling Technique}

The sampling technique used was Expert Purposive Sampling. These participants were the most suitable candidates to comment upon the inclusion of the themes of GCED and ESD in the curriculum. The participants selected were 110 which includes all (National Curriculum Review Committee) NCRC members of Pakistan and subject experts. Out of 110, a sample of 70 participants willingly participated. The positive aspect of the sample was it represented all 
four provinces of the country including Gilgit-Baltistan. The participants were $51 \%$ of Females and $49 \%$, male. The respondents mainly, were serving at higher levels in different public and private prestigious universities of Pakistan. Some as Chancellors, some as Chair Persons, Deans, Head of Departments, Professors and Lecturers.

\subsection{Instrumentation}

The instrument for the present study was taken from (IBE-UNESCO, 2016). It was adapted and used. Pilot test of the questionnaire was carried out with 15 participants of a University. For close ended questions intra and inter reliability of the items was found as 0.87 and 0.90 respectively. The open ended questions were rephrased after pilot test. The instrument was validated by three experts in Pakistan and employed after its finalization. As the questionnaire was adapted from the predetermined/A-priori themes and subthemes suggested by UNESCO the instrument was found highly reliable.

\subsection{Design of questionnaire}

The questionnaire was taken from IBE-UNESCO (2016 p 38-39) with their formal permission and the same was validated, adapted and designed on the themes of GCED and ESD.

(i) The theme of 'Human Rights' had subthemes of Rights, Democracy, Freedom, Social Justice, and Human Rights Education.

(ii) The second theme 'Education for Sustainable Development' had the subthemes of Sustainability, Ecology, and Environmental Education, Environmental Sustainability, Climate change, Renewable Energy, Waste Management, Economic Sustainability, Social Sustainability and Education for sustainable Development.

(iii) The theme of 'Peace and Non-Violence' had subthemes of peace, Abuse/Harassment and Peace Education.

(iv) Similarly 'Gender Equality' had the subthemes of Gender Equality, Gender Equity, Gender Sensitivity, Gender Parity and Empowerment.

(v) The theme of 'Global Citizenship' had the subthemes of International citizenship, Multiculturalism, Immigration, Global-Local thinking, Global competitiveness, Cultural Heritage and Global Citizenship Education.

(vi) Lastly the theme of 'Health and Well-Being' had the subthemes of Physical fitness, Mental Health, Healthy life styles, Awareness of addiction, Health Education and Sexuality Education (IBE, 2016 p 38-39).

\subsection{Data Collection}

Data for the study were collected through a survey questionnaire. As the experts were dispersed all over Pakistan the questionnaire was sent through Email for the respondents who were not reached on their address with the request 
to send the sealed envelopes on researchers' address and questionnaire was also sent through surface mail and also through special messengers and personal visits by the researchers. The responses however were received by post mail or were collected by special messengers through sealed envelopes and were also collected by the researchers personally. All efforts were made to retain the anonymity of the responses. The data were collected before the Covid 19 Pandemic. It took almost six months to get the data from the participants and for some participants soft reminders were sent so that they could respond. .

\section{Data Analysis and Interpretation}

The responses for first objective/question posed, for the close-ended questionnaire, was taken on five point Likert scale ranging from strongly agree to strongly disagree. It was analyzed through SPSS21 and the findings were expressed in descriptive statistical measure in percentages and graphs.

The second objective/question for open-ended questionnaire was analyzed by descriptive explanation, verbatim quotes and word clouds. The direct quotes enables the detailed explanation of question posed (O'Cathain \& Thomas, 2004). Verbatim responses provide accuracy of response, giving the opportunity to the respondents to openly comment (Singer \& Couper, 2017). And NVIVO 10 was used to generate word clouds which showed the frequently occurring words/ phrases related to GCED and ESD

The findings for the close ended questionnaire to get the opinions of the experts are as follows. All six themes of GCED and ESD were analyzed through SPSS21.

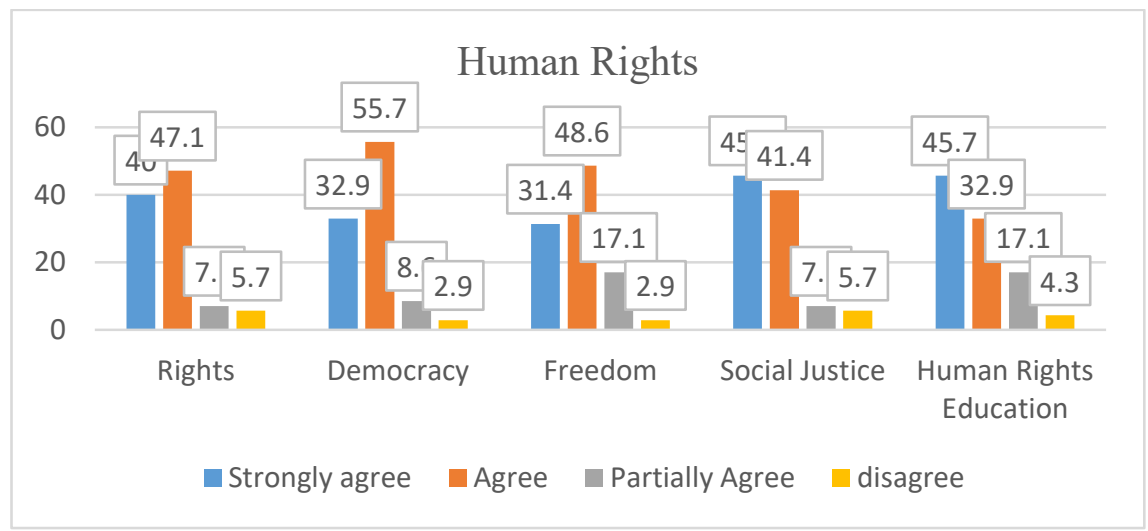

Figure 1 Perceptions for inclusion of Human Rights themes \& subthemes 
The respondents strongly agreed for the subtheme 'Rights' by $40 \%$, for 'Democracy' by $33 \%$, for 'Freedom' by $31 \%$, for 'Social Justice' by $46 \%$, for 'Human Rights Education by $46 \%$. There was very little disagreement in the main theme of Human Rights. Over all subtheme 'Social Justice' and 'Human Rights Education' were highly favored.

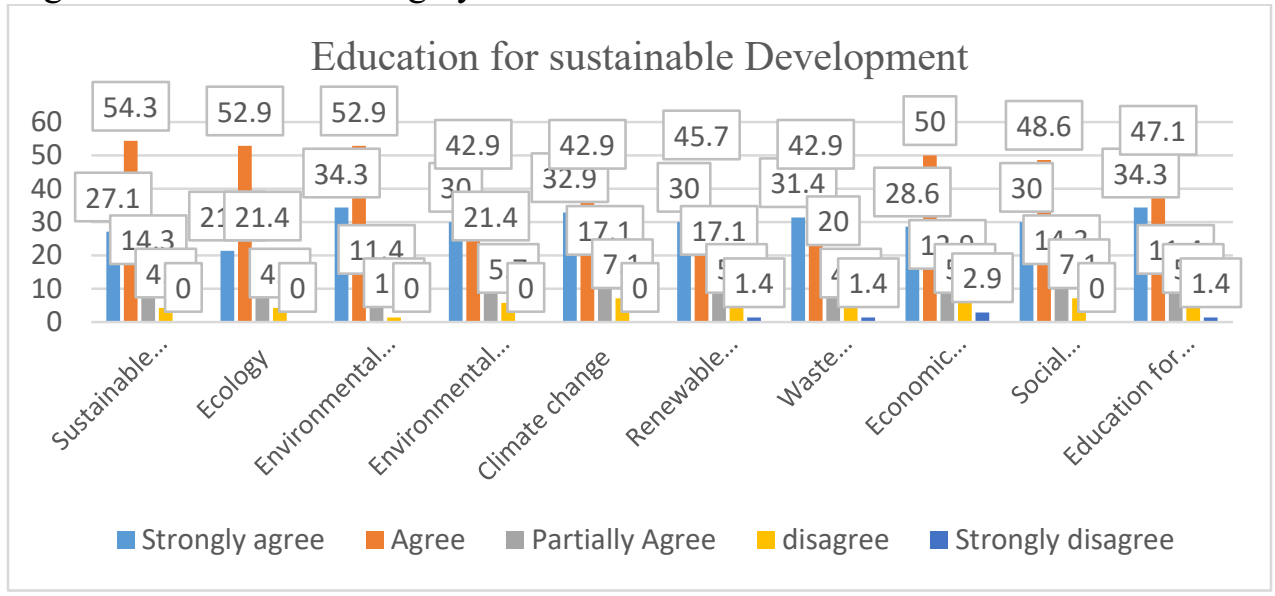

Figure 2: Perceptions for inclusion of Education for Sustainable Development subthemes

The respondents strongly agreed for the inclusion of 'Sustainability' by $27 \%$, for 'Ecology' by $21 \%$, 'Environmental education' by $34 \%$, 'Environmental sustainability by $30 \%$, for Climate change by $33 \%$, for 'Waste Management' to $31 \%$, for 'Economic Sustainability to $29 \%$, for 'Social sustainability' to $30 \%$ and lastly, Education for sustainable development' by 34\%. The most favored subtheme was 'Education for Sustainable Development'. 


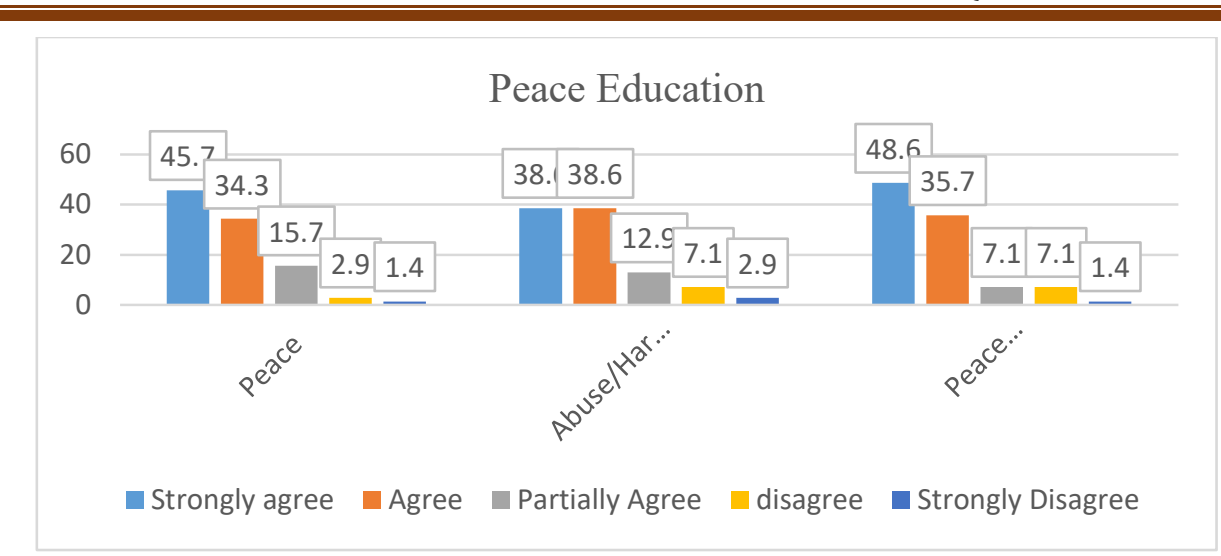

Figure 3 Perceptions for inclusion of Peace and Non-Violence subthemes

The subtheme "Peace" was strongly agreed by $46 \%$, the subtheme "Abuse/Harassment/Violence" was strongly agreed by $39 \%$ while the subtheme of "Peace Education" was strongly agreed by $49 \%$. Most favorable for inclusion was 'Peace Education'.

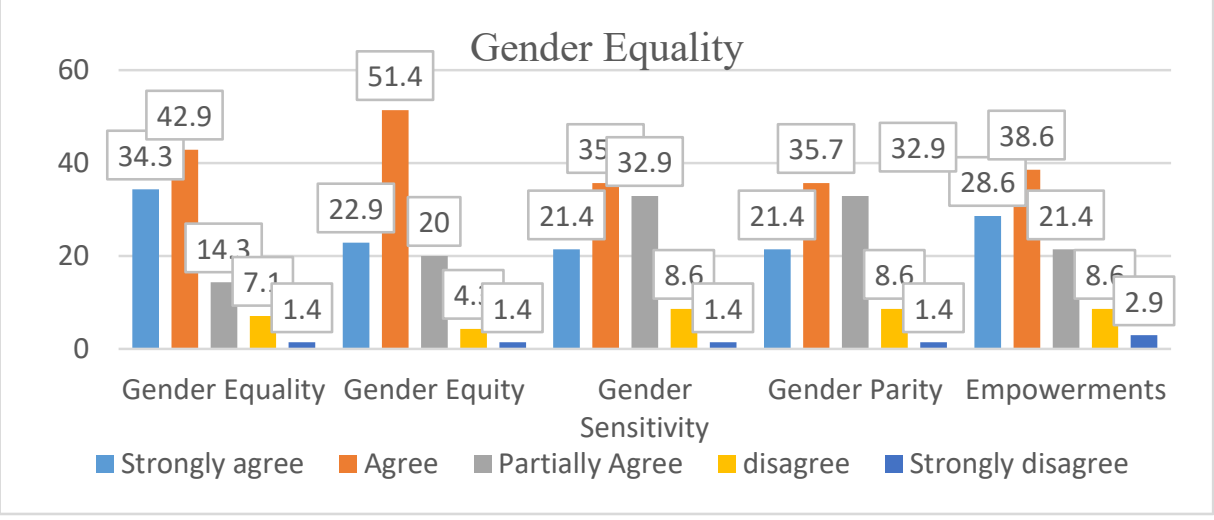

Figure 4 Perceptions for inclusion of Gender Equality subthemes

The respondents simply showed $8 \%$ disagreement, while they strongly agreed by $34 \%$ for 'Gender Equality, 'Gender Equity' was agreed by $23 \%$ whereas the subtheme of 'Gender Sensitivity' was strongly agreed by $22 \%$. 'Gender Parity' was agreed by $21 \%$ and 'Empowerments' was strongly agreed by $29 \%$. 'Gender Equality' was highly favored subtheme. 


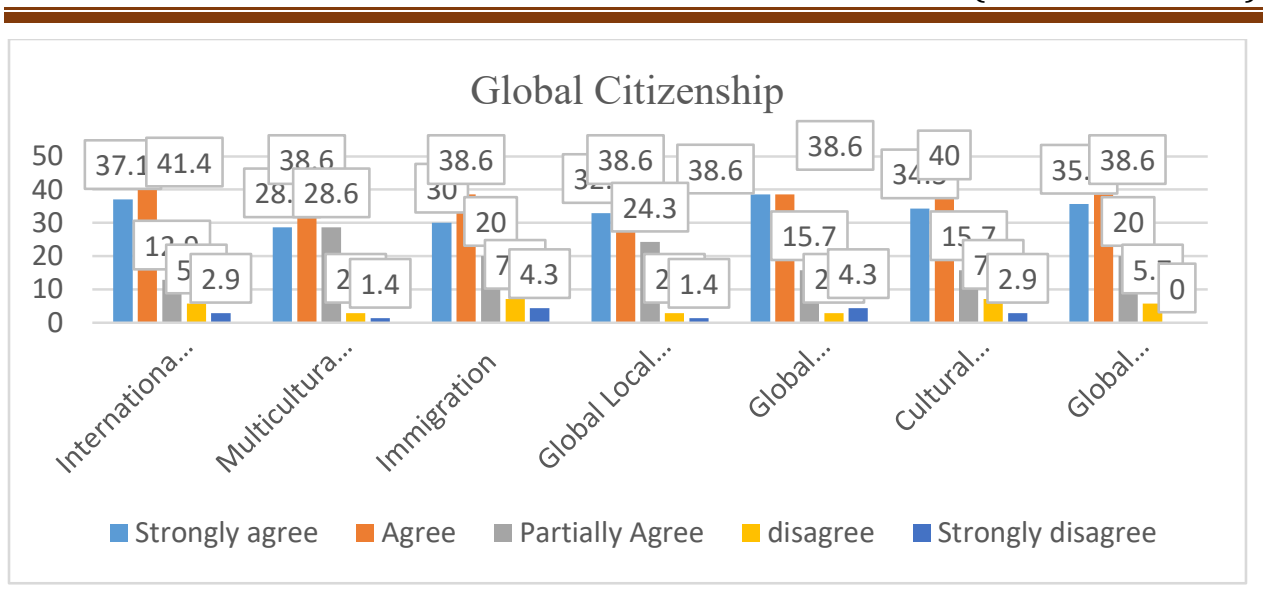

Figure 5: Perceptions for inclusion of Global Citizenship subthemes

The subthemes 'International Citizenship' was strongly agreed with $37 \%$. 'Multiculturalism' was strongly agreed by $29 \%$. 'Immigration' was strongly agreed by $30 \%$. The subtheme 'Global-Local thinking' was strongly agreed by $33 \%$ and 'Global-Competitiveness' was strongly agreed by 39\%. 'Cultural Heritage' was strongly agreed by $34 \%$. Lastly 'Global-Citizenship Education' was strongly agreed by $36 \%$, strong disagreement was seen as only $6 \%$. 'GlobalCompetitiveness' subtheme was much preferred.

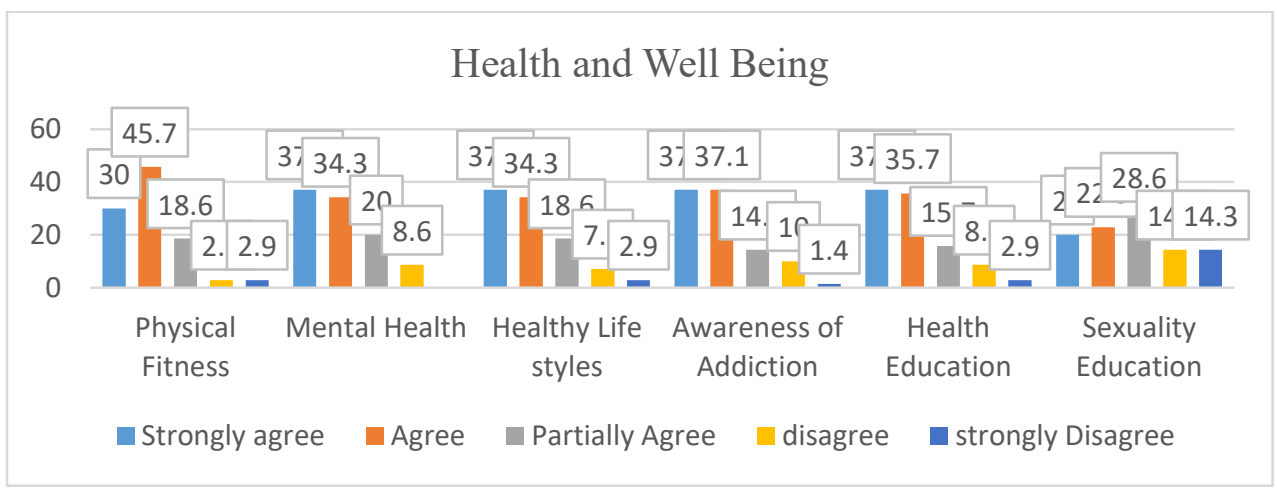

Figure 6 Perceptions for inclusion of Health \& Well-Being subthemes

The subtheme 'Physical fitness' was strongly agreed by $30 \%$, 'Mental health by $38 \%$, 'Healthy Life Styles' by $37 \%$, 'Awareness to addiction' by $37 \%$, 'Health Education by 37\%, and lastly 'Sexuality Education' by $20 \%$. 'Mental Health' was most favored. 


\section{Objective 2}

What is the opinion of Educational experts/Curriculum Developers regarding the inclusion of SDGs (Sustainable Development Goal, Target 4.7) broad themes Global Citizenship Education (GCED) and Education for Sustainable Development (ESD) in the curriculum of Pre-Service B.Ed. Honors (Elementary) and how it aids prospective teachers in the attainment of Education Agenda 2030 ?

Responding to the question, one of the participant was of the view that:

It will develop critical thinking in the prospective teachers regarding complex global issues. Moreover, it will help them recognize various countries and their cultures, identifying issues about human rights, and understanding the relationship between humans and the environment. Cross-cultural communication skills can also be developed through GCED. Inclusion of ESD in the curriculum of Pre-Service Education would be significant to develop critical thinking skills and problemsolving skills for addressing the challenges of sustainable development related to environment, society, and economics.

Participants claimed that these themes may bridge the gulf between developing and the developed countries. The social, cultural, and moral values are developed in teachers if we include these themes in B.Ed. Pre-Service curriculum.

Another participant regarding inclusion of GCED and ESD told that:

Teachers of this contemporary era must be educated to run the social process of teaching successfully and effectively. Global Citizenship education is very important to be imparted, so that we may prepare future teachers compatible with the global trends and acquire knowledge and skills to promote peace and sustainable development. Yes, inclusion of these themes and subthemes will facilitate to achieve SDGs.

Deliberating upon the subjects for the inclusion of these themes the experts were of the view that though the topics like Poverty alleviation, Pollution, Environmental Sustainability, Quality education, Communication skills are integrated in various subjects to some extent, the themes of GCED and ESD can be added to Geography, History and Social Studies.

Highlighting upon the significance GCED and ESD one of the respondent observed that:

There should be explicit inclusion/ integration of the above themes as these focus on making pre-requisite knowledge, skills and dispositions of prospective teachers. It must have trickle-down effect on the practices for elementary classroom. Integrating these themes can act as a 
proactive strategy to counter terrorism. The curriculum of Education was designed in 2012 and now it must go for periodic evaluation and redesigning keeping in view SDG. The graduates of Education subject may be given an opportunity to give feedback on their existing and preferred skills.

Emphasizing upon the importance of including GCED and ESD in the curriculum one of the ambitious participant stressed that:

Global Citizenship Education and Education for sustainable development as agents of change, will sustain, if and only if all the related themes and subthemes are explicitly included in elementary school curriculum as well as in Pre-service B.Ed. Elementary curriculum. These two pillars can be used to build strong sustainable development program. They can either be integrated in the existing subjects or can be introduced as separate subjects with additional credit hours.

Participants demanded that to ensure the teaching of Global Citizenship and Education for Sustainable Development is being carried out, it is necessary to take the assessments related to GCED and ESD practices at both the formative and the summative level.

An interesting comment from one of the participant was that:

There is no second opinion regarding their inclusion, as this is the only way to prepare the society to achieve the goal of Education Agenda 2030. If Pakistan expects to prepare its youth to be reflective, problem solving and make contribution to an Islamic, Ethical and Progressive Pakistan, then not paying attention to SDG goals will leave Pakistan less competent with those who have attained these.

Some of the respondents did not favor the inclusion of GCED and ESD and told that there is no need to include these themes. 


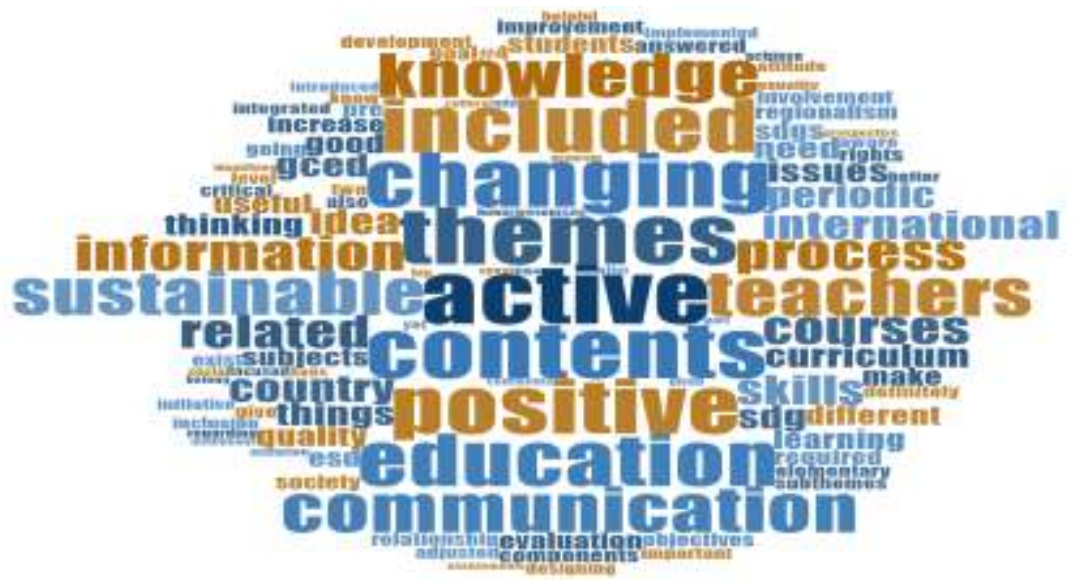

Figure 7. Word Cloud for inclusion of GCED and ESD themes in B.Ed. curriculum

\section{Discussion}

The Sustainable development goals, Target 4.7 stresses upon all nations of the globe to incorporate GCED and ESD in the policies, plans, curricula and assessment strategies including teacher education program. As the topic is quite novel in Pakistan, not many studies were found on this particular topic rather many of the scholars in Pakistan have investigated B.Ed. Curricula to see the inclusion of the theme of Education for Sustainable Development (ESD) which was the then umbrella term before the SDGs (2015-2030) were framed. The pedagogies suggested for teaching global citizenship and the pedagogies referred by Rizvi (2015) as per the present B.Ed. (Honors) elementary curriculum are almost similar with few more addition in teaching GCED. Restricted response findings showed that all the participants except very few highly favored the inclusion of the six main themes and their subthemes in the B.Ed. curricula. The present study is in consensus with Durrani, Malik, \& Jumani (2019) where the NCRC members highly favored the inclusion of the themes of tolerance, peace, preservation of cultural heritage and natural resources. They were also in agreement for the inclusion of the themes of International Understanding and the Citizen's Rights. Similarly they showed their accord with the study participants in recommending for the revision of curriculum of B.Ed. (Honors). Unanimity of the present study is also seen with the findings of Kalsoom \& Qureshi (2019) who investigated the inclusion of ESD in the B.Ed. (Honors) and other teacher preparation documents and found that the component of ESD inclusion was only $5 \%$ and suggested for wider inclusion of this concept in the teacher education 
program to keep pace with the international community. The study participants under discussion expressed similar view that inclusion of GCED and ESD in the B.Ed. curriculum will improve critical thinking, cross cultural communication skills and build International Understanding. The study of IBE-UNESCO (2016) also expressed similar views. The present study findings do not show unanimity with (UNESCO, 2016b) where some of the participants, do not find the need for the inclusion of GCED and ESD. The findings of current study shows agreement with Pasha (2015) who wants the citizens of Pakistan to be given opportunity to interact with the world community so that they get to know themselves as citizens and their duties beyond the state. The present study also showed agreement with the study of Amin, Jumani, \& Malik (2020) who asserted the inclusion of 'Peace' for the benefit of society and the individual. The study participants' expressed similar opinion saying inclusion of these themes can act as a proactive strategy to counter terrorism. UNESCO (2016b) in its Global Monitoring report on Education shows consensus with the present study saying that Global Citizenship Education will prepare teachers to get knowledge and skills regarding universal trends and issues enabling them to develop global understanding and help them avoid regional prejudice which is vital to enhance quality of education. Similar views were also expressed by the study participants.

\section{Conclusion}

From the study, it is concluded that Pre-Service Teacher Education is very significant and inclusion of these themes will allow the prospective teachers to attain critical thinking about multifaceted global issues and help them to know their relation with the fellow humans and the environment they live in. It can develop compatibility of the prospective teachers with the global trends. The present B.Ed. curriculum has sufficient pedagogies but lacks the content base as identified and also needs teacher preparation. GCED and ESD are cross cutting themes and are two pillars which can build strong sustainable futures. Hence the present teacher education curriculum must be revised as it was prepared in 2012 and has not yet been updated. These themes can be integrated in the present subjects to give more effective results or it can be introduced as separate subjects. Above all its inclusion will aid in achieving 'Quality in education' and ultimately help the achievement of broad 'SDG goals' and 'Education Agenda 2030'.

\section{Recommendations}

1. According to Experts of Curriculum design, Global Citizenship Education (GCED) and Education for Sustainable development (ESD) are cross-cutting themes, so these themes may be integrated across all subjects and the curriculum may be amended for the inclusion of these themes at B.Ed. Honors level. 
2. As GCED and ESD are three dimensional and interrelated, therefore stakeholders and experts related to the Economic sector, Social and Cultural Affairs, Environmentalists along Educational experts may sit together to either integrate the components of GCED and ESD at all levels across the curricula or design it separately.

3. The curricula may carefully be designed to avoid gender biases. The teacher educators may be trained so that they develop collaborative, problem-solving, critical thinking, and cross-cultural communication skills. Sufficient financial support may be granted to arrange workshops, seminars, and training for both the In-Service and Pre-Service teachers.

4. Similarly, training may especially be arranged for college and school head teachers so that the whole school application of GCED and ESD gets implemented. National Education Policy and all education-related documents like National Professional Standards for Teachers document, National Accreditation for Teacher Educational Programme document and the curricula for School and Teachers education may be reviewed in the light of GCED and ESD and the same may be incorporated in these documents.

\section{References}

Aamer, L. C. M. (2009). Existing education system of Pakistan psycho-social and socio-economic effects. NDU Journal, 13, 131.

Ahmad, I. (2014). Critical Analysis of the Problems of Education in Pakistan: Possible Solutions. International Journal of Evaluation and Research in Education, 3(2), 79-84.

Amin, S., Jumani, N., \& Malik, S. (2020). Integrating Peace Education in PreService Teachers Training Programs: Views from Teacher Educators and Prospective Teachers in Pakistan. International Journal of Service Management and Sustainability, 4(1), 67. doi: 10.24191/ijsms.v4i1.8059

Chishti, S. U. H., Tahirkheli, S. A., Raja, S. A., \& Khan, S. B. (2011). Quality School Education in Pakistan: Challenges, Successes and Strategies. International Journal of Academic Research, 3(2).

Cohen, L., Manion, L., \& Morrison, K. (2013). Research methods in education. Routledge.

Cox, C. (2017). Global citizenship concepts in curriculum guidelines of 10 countries: Comparative analysis. Retrieved 23 December 2018, from 
https://unesdoc.unesco.org/ark:/48223/pf0000247788?_ga=2.226951193. 568845328.1598216737-1886908474.1598039630

Desa, U. N. (2016). Transforming our world: The 2030 agenda for sustainable development. Retrieved 25 June 2019, from https://sustainabledevelopment.un.org/post2015/transformingourworld/p ublication

Durrani, R., Malik, S., \& Jumani, N. B. (2019). Education for sustainable development (ESD) in pre-service teachers' education curriculum at Pakistan: Current status and future directions. Pakistan Journal of Distance and Online Learning, 5(2), 67-84.

Haider, G. (2016). Process of Curriculum Development in Pakistan. International Journal of New Trends in Arts, Sports \& Science Education (IJTASE), 5(2).

Higher Education Commission (2012). The curriculum of Education. Islamabad: Higher Education Commission.

IBE (2016). Global Monitoring of GCED \& ESD: Themes in School Curricula. (Background paper for Global Education)

IBE-UNESCO. (2016). Global Monitoring of Target 4.7: Themes in National Curriculum Frameworks. Paris, France.

Iqbal, H., Afzal, S., \& Inayat, M. (2012). Gender Discrimination: Implications for Pakistan Security. IOSR Journal of Humanities and Social Science, 1(4), 16-25.

Kalsoom, Q., \& Qureshi, N. (2019). Teacher Education for Sustainable Development in Pakistan: Content Analysis of Teacher Education Curriculum and Standards. SSRN Electronic Journal. doi: $10.2139 /$ ssrn. 3388457

Laurie, R., Nonoyama-Tarumi, Y., Mckeown, R., \& Hopkins, C. (2016). Contributions of education for sustainable development (ESD) to quality education: A synthesis of research. Journal of Education for Sustainable development, 10(2), 226-242.

Lewin, K. M. (2016). Curriculum Assessment and Education for Sustainable Development: Does the Emperor have New Clothes? 
Lirola, M. M. (2017). Introducing education based on human rights in higher education: Examples from a language subject. Indonesian Journal of Education, 9(2), 82-88. doi: dx.doi.org/10.17509/ije.v9i2.5461

Marope, M., Griffin, P., \& Gallagher, C. (2017). Future competences and the future of curriculum: A global reference for curricula transformation. Paris: International Bureau of Education.

O'Cathain, Alicia \& Thomas, Kate. (2004). Any other comments? Open questions on questionnaires - A bane or a bonus to research?. BMC medical research methodology. 4. 25. 10.1186/1471-2288-4-25.

Osiadacz, E. (2018). Global Citizenship. Brock Education. A Journal of Educational Research and Practice, 27(2), 44-47.

Osman, A., Ladhani, S., Findlater, E., \& McKay, V. (2017). Curriculum Framework for the Sustainable Development Goals. London: The Commonwealth Secretariat.

Pasha, A. (2015). Global Citizenship in Pakistan. International Journal of Development Education and Global Learning, 7(1), 33-52.

Pirzado, P. (2019). Teaching Human Rights In Pakistani Schools: What Are The Potential Barriers? PEOPLE: International Journal of Social Sciences, 4(3), 1741-1760. doi: 10.20319/pijss.2019.43.17411760

Rieckmann, M. (2017). Education for sustainable development goals: Learning objectives. UNESCO Publishing.

Rizvi, M. (2015). Teacher education pedagogies related to preparing pre-service teachers as leaders in Pakistan. International teacher education: Promising pedagogies (Part B), 22(B), 7-30.

Education 2030: Incheon Declaration and Framework for Action Towards inclusive and equitable quality education and lifelong learning for all UNESCO IITE. Retrieved 30 December 2018, from https://iite.unesco.org/publications/education-2030-incheon-declarationframework-action-towards-inclusive-equitable-quality-educationlifelong-learning/

UNESCO. (2013). Global citizenship education: Preparing learners for the challenge of the $21^{\text {st }}$ century. United Nations Educational, Scientific, and Cultural Organization (UNESCO). 
UNESCO. (2014). UNESCO Education Strategy 2014-2021. Retrieved 11 June 2016 , from https://www.empowerwomen.org/en/resources/documents/2015/2/unesco -education-strategy-20142021?lang=en

UNESCO. (2015). A Guide for Gender Equality in Teacher Education Policy and Practices. UNESCO

UNESCO. (2016a). Unpacking Sustainable Development Goal 4 Education 2030: Guide. Retrieved 20 December 2017, from https://unesdoc.unesco.org/ark:/48223/pf0000246300

UNESCO. (2016b). Education for People and Planet: Creating Sustainable Futures for All: Global Education Monitoring Report. Retrieved 11 December 2017, from https://en.unesco.org/gemreport/report/2016/education-people-and-planet-creating-sustainablefutures-all

\section{Citation of this Article:}

Bano, N., \& Hina, K. (2020). Inclusion of Global Citizenship Education and Sustainable Development in Pre-Service Curriculum: A Perspective Study. International Journal of Innovation in Teaching and Learning (IJITL), 6(2), 95112. 